\title{
Soil Test Based Inorganic Fertilizer and Integrated Plant Nutrition System for Rice (Oryza sativa L.) Cultivation in Inceptisols of Bangladesh
}

\author{
M. I. Ullah Sarkar ${ }^{1}$, M. M. Rahman ${ }^{2}$, G.K.M. M. Rahman' ${ }^{2}$, U. A. Naher ${ }^{1}$ and M. N. Ahmed ${ }^{1}$ \\ ${ }^{1}$ Soil Science Division, Bangladesh Rice Research Institute, Gazipur-1701, Bangladesh \\ ${ }^{2}$ Department of Soil Science, Bangabandhu Sheikh Mujibur Rahman Agricultural University, \\ Gazipur-1706, Bangladesh \\ *Corresponding author and Email: imranbsmrau@gmail.com
}

Received: 10 February 2016

Accepted: 12 June 2016

\begin{abstract}
A field experiment was conducted at the Bangladesh Rice Research Institute, Gazipur during 2013 to study the potential of different organic materials in integrated plant nutrition system (IPNS) and soil test based (STB) inorganic fertilizer on the growth, nutrient uptake and yield of rice (Oryza sativa L.): variety BRRI dhan29. Five treatments were laid out in a randomized complete block design with four replications. The treatments were: (1) soil test based inorganic fertilizer (NPKS @ 138-7-80-3 $\mathrm{kg} \mathrm{ha}^{-1}$ ), (2) cow dung $\left(3 \mathrm{t} \mathrm{ha}^{-1}\right)$, (3) poultry manure $\left(2 \mathrm{t} \mathrm{ha}^{-1}\right)$, (4) mustard oil cake $\left(2 \mathrm{t} \mathrm{ha}^{-1}\right)$ and (5) control. Organic fertilizers were applied on dry weight basis. Inorganic fertilizers were applied along with poultry manure (PM), cow dung (CD) and mustard oil cake (MOC) as IPNS. Soil test based STB fertilizer and PM in IPNS provided maximum grain yield of rice $\left(6.11 \mathrm{t} \mathrm{ha}^{-1}\right)$. Maximum plant height and tiller numbers were found in MOC treatment, while the numbers of filled grains were higher in STB fertilizer and PM treated plots. The application of different organic sources as IPNS significantly influenced the N, P, K and S uptake in rice. However, the highest N, P, K and S uptake were found in the PM treatment. The benefit cost ratio of different treatments followed the order of $\mathrm{STB}>\mathrm{PM}>\mathrm{CD}>\mathrm{C}$ Control $>\mathrm{MOC}$. Considering yield potential and BCR, STB fertilizer and PM treatments were found economically profitable. However, from environmental point of view and sustainable management of soil health and crop productivity, application of PM and CD in rice-rice cropping system is recommended for rice cultivation.
\end{abstract}

Keywords: Integrated plant nutrition system, rice, benefit cost ratio, nutrient uptake

\section{Introduction}

Rice (Oryza sativa L.) is the most important food crop and staple food in Bangladesh. Rice is grown on about 11.53 million hectares of land with annual production of 33.54 million tons which contributes one-half of the agricultural GDP and one-sixth of the national income of the country (BBS, 2011). The population of Bangladesh is still growing by two million every year and may increase by another 30 million over the next 20 years (Magor et al., 2007). Thus, Bangladesh will require about 44.6 million tons of rice for the year 2050 (Kabir et al., 2016). Rice, therefore, needs to be grown using such technologies that will sustain rice yield and maintain soil health.

The use of inorganic fertilizers in modern agriculture is progressively increasing and the 
trend is likely to continue so in future to produce more agricultural products for ever increasing population. Adoption of modern technology followed by high cropping intensity has caused the soils of Bangladesh to be deficient in organic matter and essential plant nutrients like nitrogen, phosphorus, potassium and sulphur (Hoque and Jahiruddin, 1994; Karim et al., 1994; Ali et al., 1997). Extensive agricultural intensification and modern technology associated with higher use of inorganic fertilizers are resulting in serious degradation of soil physicochemical properties (Singh et al., 2014). Ali et al. (2009) reported that continuous and repeated use of inorganic fertilizers alone fails to sustain desired yield, impairs the physical condition and reduces organic matter content of soils. Hence, a good supply of organic matter is essential for sustaining soil fertility and crop productivity. However, it is true that sustainable crop production cannot be maintained by using inorganic fertilizers alone, and similarly, it is not possible to obtain higher crop yield by using only organic manure.

Combined application of nutrients using organic and inorganic sources in soil could be considered as one of the best management practices in sustainable agriculture (Rahman et al., 2015). The interactive advantages of combining organic and inorganic nutrients in integrated nutrient management have proved superior to the use of each component separately (Palaniappan and Annadurai 2007; Rahman, 2007).

Therefore, integrated use of organic manures and inorganic fertilizers as soil test basis which is termed as integrated plant nutrition system (IPNS) could be quite promising for maintaining sustainable crop production as well as soil fertility. Though work has been done with organic manure and inorganic fertilizer, little information is available on integrated plant nutrition system (IPNS) for rice production in Bangladesh. Considering the facts, the investigation was carried out to assess the comparative potential of different organic fertilizers such as cow dung, poultry manure and mustard oil cake as the component of IPNS, and soil test based inorganic fertilizer for enhancing yield and nutrient uptake of rice.

\section{Materials and Methods}

The field experiment was conducted at the Soil Science research field of Bangladesh Rice Research Institute, Gazipur during January to May 2013. The experimental site lies between $29.59^{\circ} \mathrm{N}$ latitude and $90.24^{\circ} \mathrm{E}$ longitude with an elevation of $8.4 \mathrm{~m}$ from sea level. The soil of the experimental site belongs to the order Inceptisols in USDA soil classification. The experiment was laid out in a randomized complete block design with four replications. The treatments were: 1)soil test based (STB) dose, 2) STB + Cow dung @ $3 \mathrm{t} \mathrm{ha}^{-1}$ as IPNS, 3) STB + Poultry manure (PM)@2 $\mathrm{t} \mathrm{ha}^{-1}$ as IPNS, 4) STB + Mustard oil cake (MOC) @ $2 \mathrm{t} \mathrm{ha}^{-1}$ as IPNS and 5) control. Rice variety BRRI dhan 29 was used as test crop. All of the organic sources were applied as dry weight basis. Before transplanting the rice seedlings, samples of initial soil and the used organic manures were collected for analyzing their inorganic properties. The initial soil contains $2.10 \%$ total organic matter, $0.11 \%$ total $\mathrm{N}, 19 \mathrm{mg} \mathrm{kg}^{-1}$ available $\mathrm{P}, 0.14 \mathrm{meq} \mathrm{K}$ in $100^{-1} \mathrm{~g}$ soil and $28 \mathrm{mg} \mathrm{kg}^{-1}$ available $\mathrm{S}$. The $\mathrm{N}, \mathrm{P}$ and $\mathrm{K}$ contents in cow dung, poultry manure and mustard oil cake are shown in Table 1.

Table 1. Nutrient content (\%) of the cow dung, poultry manure and mustard oil cake

\begin{tabular}{lccc}
\hline \multirow{2}{*}{ Organic source } & \multicolumn{3}{c}{ Nutrient content $(\%)$} \\
\cline { 2 - 4 } & $\mathrm{N}$ & $\mathrm{P}$ & $\mathrm{K}$ \\
\hline Cow dung & 0.50 & 0.15 & 0.50 \\
Poultry manure & 1.90 & 0.56 & 0.75 \\
Mustard oil cake & 5.00 & 1.80 & 1.20 \\
\hline
\end{tabular}




\subsection{Application of organic fertilizers and transplanting of rice}

Well decomposed CD, PM and MOC were applied to the respective treatments one week before final land preparation. Based on the nutrient (NPKS) properties of initial soil and organic manures used, fertilizers rates were calculated using fertilizer recommendation guide of Bangladesh Agricultural Research Council (BARC, 2012). Phosphorous from triple super phosphate (TSP), potassium from muriate of potash and sulphur from gypsum were applied at the time of final land preparation. Nitrogen from urea was applied in three equal splits. One-third of urea was applied at the time of final land preparation. The remaining two-third was top dressed at maximum tillering stage and 5-7 days before panicle initiation stage of crop growth. Forty five-day old seedlings of BRRI dhan29 having $7.5 \mathrm{t} \mathrm{ha}$ yield potential were transplanted with spacing $20 \mathrm{~cm} \times 20 \mathrm{~cm}$ on January 10, 2013 and harvested at maturity on May 20, 2013.

\subsection{Grain yield and nutrient content analyses}

Plant samples were collected at panicle initiation and maturity stage for nutrient analysis. Total nitrogen content was estimated by Micro Kjeldhal method (Bremner, 1965) and P, K and $\mathrm{S}$ contents were determined by nitric-perchloric acid digestion method (Yamakawa, 1992). The nutrient uptake was calculated as:

Nutrient uptake $\left(\mathrm{kg} \mathrm{ha}^{-1}\right)=$ Nutrient content $(\%)$ $\times$ Yield $\left(\mathrm{t} \mathrm{ha}^{-1}\right) \times 10$ (1)

For estimation of grain yield, the crops were harvested at maturity. Grain yield was calculated from a harvesting area of $5 \mathrm{~m}^{2}$ and adjusted to $14 \%$ moisture content. Straw yield was calculated on oven dry basis from randomly collected 16 hills.

\subsection{Statistical analysis}

Data were statistically analyzed using CropStat7.2 and SPSS16.0 statistical software following the F-test and the mean comparisons were made by DMRT (Gomez and Gomez, 1984 ) at the $5 \%$ level of significance. Economic analysis was carried out to estimate net return and benefit cost ratio.

\section{Results and Discussion}

\subsection{Plant height and yield parameters of rice} Application of MOC @ $2 \mathrm{tha}^{-1}$ as IPNS increased plant height similar to STB inorganic fertilizer and it was significantly higher than IPNS based CD and PM treatments (Table 2). Similar increase in number of tillers and panicles per $\mathrm{m}^{2}$ were also observed with MOC applied in IPNS treatments. Application of organic materials improves soil physical, chemical and biological properties and thereby improves soil health which favors root penetration and expands nutrient acquisition areas and ultimately increases yield and yield contributing characters. Ofori et al. (2005) reported an increase in the number of effective tillers in rice due to organic manure application which endorses our findings. On the other hand, higher number of filled grains per panicle was found in STB inorganic fertilizer which was statistically similar to IPNS based PM treatment. In case of 1000 grain weight there was no significant difference among STB inorganic and different sources of organic manures as IPNS. However, control treatment gave lowest plant height and other yield parameters compared to STB inorganic and IPNS treatment.

\subsection{Grain and straw yield}

Application of STB inorganic fertilizers and different organic sources as IPNS produced significantly higher grain and straw yields over the control treatment. Application of PM and MOC produced rice yield which was statistically similar to that given by STB inorganic fertilizers (Figure 1). On the other hand, the use of CD produced significantly lower grain yield than STB fertilizers and PM treatments. Shah et al. (2008) reported that application of STB dose covering major nutrient elements produced maximum rice yield. Though application of soil test based inorganic fertilizers was found to be efficient in producing higher crop yields for the time being, in the long run, it certainly degrades soil health and reduces crop yields. 
Many researchers reported positive results of combined application of organic and inorganic fertilizers application in rice and many other vegetables (Rahman, 2013; Rahman et al., 2015). The highest straw yield was obtained from MOC applied plot compared to STB and other organic manures treated plots. The reason for higher straw yield in this treatment might be due to increased plant height and higher number of tillers per $\mathrm{m}^{2}$.

Table 2. Effect of soil test based inorganic fertilizer and integrated plant nutrient system on plant height and yield parameters of BRRI dhan29

\begin{tabular}{llllll}
\hline Treatments & $\begin{array}{c}\text { Plant height } \\
(\mathrm{cm})\end{array}$ & $\begin{array}{c}\text { Tiller per } \\
\mathrm{m}^{2}\end{array}$ & $\begin{array}{c}\text { Panicle per } \\
\mathrm{m}^{2}\end{array}$ & $\begin{array}{c}\text { Filled grains per } \\
\text { panicle }\end{array}$ & $\begin{array}{c}1000 \text { grain } \\
\text { weight }(\mathrm{g})\end{array}$ \\
\hline STB & $101.0 \mathrm{ab}$ & $277 \mathrm{~b}$ & $265 \mathrm{~b}$ & $105.75 \mathrm{a}$ & $24.19 \mathrm{a}$ \\
CD as IPNS & $97.75 \mathrm{~b}$ & $257 \mathrm{c}$ & $247 \mathrm{ab}$ & $99.25 \mathrm{~b}$ & $23.48 \mathrm{a}$ \\
PM as IPNS & $98.50 \mathrm{~b}$ & $281 \mathrm{ab}$ & $271 \mathrm{c}$ & $102.50 \mathrm{ab}$ & $24.18 \mathrm{a}$ \\
MOC as IPNS & $104.0 \mathrm{a}$ & $294 \mathrm{a}$ & $279 \mathrm{a}$ & $100.50 \mathrm{~b}$ & $23.78 \mathrm{a}$ \\
Control & $79.40 \mathrm{c}$ & $132 \mathrm{~d}$ & $129 \mathrm{~d}$ & $68.75 \mathrm{c}$ & $21.55 \mathrm{~b}$ \\
\hline CV\% & 3.00 & 4.0 & 6.1 & 3.4 & 3.3 \\
S.E. $( \pm)$ & 1.42 & 5 & 7 & 1.20 & 0.12 \\
\hline
\end{tabular}

*Means in a column followed by same letter (s) are not significantly different at 5\% level of significance by DMRT

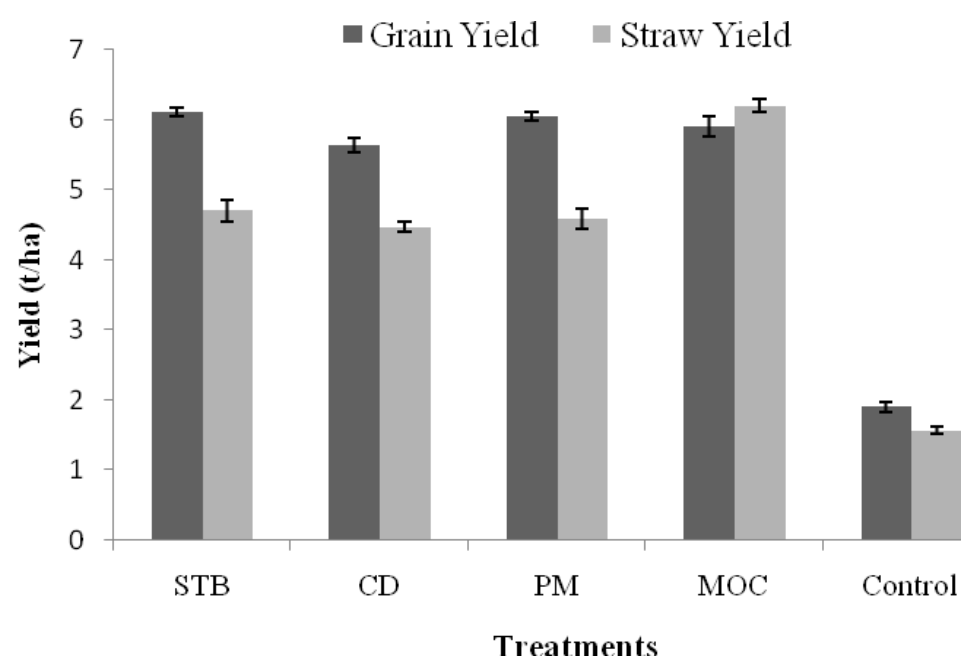

Figure 1. Influence of STB inorganic fertilizer and different organic sources as IPNS on grain and straw yields of BRRI dhan29 (Grain contains 14\% moisture, while straw as oven dry basis) 


\subsection{Nutrient content and uptake at panicle initiation stage in rice}

Different treatments showed significant effects on tissue nutrient contents and their uptake (Table 3). Significantly higher N uptake was found in PM applied soil and the lowest was in the control soil. Cow dung, MOC and STB treatments were found to be statistically similar in case of $\mathrm{N}$ uptake. Nitrogen content of rice plants at panicle initiation stage was found higher in PM treatment compared to other treatments (Table 3). Significantly higher $P$ uptake was found in PM treated soil compared to CD applied soil but similar with STB and MOC treatments. It means that the content of $\mathrm{P}$ in PM was more bio-available for rice plants compared to $\mathrm{CD}$. The highest $\mathrm{K}$ content in plant was found when STB fertilizers were applied which was identical with $\mathrm{CD}$ treatment. Application of organic manures as IPNS and STB fertilizers did not show significant differences in $\mathrm{S}$ uptake by rice plants. Plant tissue nutrient content at panicle initiation stage is important as yield determining factors like grains per panicle and numbers of panicles per unit area are fixed at this stage, which might have a strong positive influence on rice yield.

\subsection{Nutrient content and uptake in straw and grain at harvest}

The use of PM in soil significantly increased $\mathrm{N}$ and $\mathrm{P}$ contents in rice grains compared to sole application of STB fertilizers (Table 4). Significant effects of manures and inorganic fertilizers on the grain $\mathrm{N}$ and $\mathrm{P}$ contents of rice and different vegetables were reported by many researchers (Roul and Sarawgi, 2005; Rahman, 2013; Rahman et al., 2015). The combined applications of organic and inorganic fertilizers were found always better in terms of soil health improvement and crop productivity (Rahman, 2013; Rahman et al., 2015). Poultry manure contains all nutrients in higher amounts compared to many other organic manures and fertilizers like cow dung, composts etc. In case of grain K content, statistically similar effect was found in PM and STB treatments. Significantly higher S content in grain was observed with MOC and PM treated plots compared to STB treatment. Hossain (1996) also found that $S$ content in grain was increased due to application of organic manure in association with $\mathrm{N}, \mathrm{P}, \mathrm{K}$, and $S$ inorganic fertilizers in rice field. Application of STB doses of inorganic fertilizers contributed to the highest contents of $\mathrm{N}$ and $\mathrm{S}$ in straw than application of different organic manures as IPNS (Table 4). Application of PM was found equally efficient with STB fertilizers in increasing the $\mathrm{P}$ content in straw. But significant increased in $\mathrm{K}$ content of straw was observed in PM treated plot compared to STB treatment.

Solitary application of inorganic fertilizers and combined application of both organic and inorganic fertilizers significantly increased $\mathrm{N}, \mathrm{P}$, $\mathrm{K}$, S uptake by rice straw and grain over the control treatment (Table 5). Rahman (2013) reported similar findings in rice and tomato where poultry manure, cow dung and household waste composts were applied. Sharma and Mitra (1991) also reported a significant increase in $\mathrm{N}$ uptake with $5 \mathrm{t} \mathrm{ha}^{-1}$ of FYM in rice based cropping system. In IPNS, the uptake of N, P and $\mathrm{K}$ by straw were found maximum with the application of PM and MOC even than STB inorganic fertilizer. With few exceptions similar increased uptake trend was observed in grain. With the same source maximum uptake of $\mathrm{S}$ was observed in straw. Ritamoni et al. (1999) reported a significant increase in $\mathrm{N}, \mathrm{P}$ and $\mathrm{K}$ uptake through organic sources of nutrient.

\subsection{Total uptake of N, P, K and S at harvest}

Total uptake of N, P, K and S by rice plant was significantly increased with the application of STB inorganic and organic manures as IPNS than control treatment (Table 5). Application of PM@ $2 \mathrm{t} \mathrm{ha}^{-1}$ with inorganic fertilizer as IPNS significantly increased total uptake of $\mathrm{N}, \mathrm{P}, \mathrm{K}$ and $S$ than STB inorganic dose. In case of other organic sources the uptake scenario of specific nutrient element level has some relationship with 
PM but not consistent. PM was found in most of the cases superior to other organic fertilizers in supplying nutrients and producing crop yields which is supported by many researchers (Vanaja and Raju, 2002; Shah et al., 2008; Rahman,
2013; Rahman et al., 2015). It seems among the organic sources, PM can be considered as a potential candidate in maintaining soil fertility and increasing crop yields which may forward at least one step towards sustainable agriculture.

Table 3. Effect of soil test based inorganic fertilizer and integrated plant nutrient system on $\mathrm{N}, \mathrm{P}, \mathrm{K}$ and $\mathrm{S}$ content and uptake at panicle initiation stage by BRRI dhan29

\begin{tabular}{lcccccccc}
\hline Treatments & \multicolumn{3}{c}{ Nutrient content (\%) } & \multicolumn{5}{c}{${\text { Total uptake }\left(\mathrm{kg} \mathrm{ha}^{-1}\right)}$} \\
\cline { 2 - 9 } & $\mathrm{N}$ & $\mathrm{P}$ & $\mathrm{K}$ & $\mathrm{S}$ & $\mathrm{N}$ & $\mathrm{P}$ & $\mathrm{K}$ & $\mathrm{S}$ \\
\hline STB & $1.68 \mathrm{bc}$ & $0.30 \mathrm{ab}$ & $2.10 \mathrm{a}$ & $0.17 \mathrm{ab}$ & $41.71 \mathrm{~b}$ & $7.32 \mathrm{ab}$ & $51.83 \mathrm{a}$ & $4.09 \mathrm{a}$ \\
CD as IPNS & $1.64 \mathrm{c}$ & $0.28 \mathrm{~b}$ & $2.00 \mathrm{ab}$ & $0.19 \mathrm{a}$ & $41.59 \mathrm{~b}$ & $6.99 \mathrm{~b}$ & $50.63 \mathrm{a}$ & $4.72 \mathrm{a}$ \\
PM as IPNS & $1.88 \mathrm{a}$ & $0.32 \mathrm{a}$ & $1.90 \mathrm{~b}$ & $0.16 \mathrm{ab}$ & $51.71 \mathrm{a}$ & $8.86 \mathrm{a}$ & $52.73 \mathrm{a}$ & $4.54 \mathrm{a}$ \\
MOC as IPNS & $1.73 \mathrm{~b}$ & $0.28 \mathrm{~b}$ & $1.67 \mathrm{c}$ & $0.17 \mathrm{ab}$ & $46.60 \mathrm{ab}$ & $7.60 \mathrm{ab}$ & $45.07 \mathrm{a}$ & $4.51 \mathrm{a}$ \\
Control & $1.21 \mathrm{~d}$ & $0.16 \mathrm{c}$ & $1.39 \mathrm{~d}$ & $0.14 \mathrm{~b}$ & $7.55 \mathrm{c}$ & $0.98 \mathrm{c}$ & $8.71 \mathrm{~b}$ & $0.89 \mathrm{~b}$ \\
\hline CV\% & 4.0 & 7.3 & 4.5 & 11.3 & 16.20 & 18.60 & 19.00 & 17.50 \\
S.E. $( \pm)$ & 0.02 & 0.003 & 0.04 & .001 & 3.07 & 0.58 & 3.98 & 0.33
\end{tabular}

*Means in a column followed by same letter (s) are not significantly different at 5\% level of significance by DMRT

Table 4. Effect of soil test based inorganic fertilizer and integrated plant nutrient system on N, P, K and $\mathrm{S}$ content in grain and straw of BRRI dhan29

\begin{tabular}{|c|c|c|c|c|c|c|c|c|}
\hline \multirow[t]{3}{*}{ Treatments } & \multicolumn{4}{|c|}{ Grain } & \multicolumn{4}{|c|}{ Straw } \\
\hline & \multicolumn{8}{|c|}{ Content $\%$} \\
\hline & $\mathrm{N}$ & $\mathrm{P}$ & $\mathrm{K}$ & $S$ & $\mathrm{~N}$ & $\mathrm{P}$ & K & $\mathrm{S}$ \\
\hline STB & $1.13 \mathrm{~b}$ & $0.23 \mathrm{~b}$ & $0.26 \mathrm{a}$ & $0.08 \mathrm{~b}$ & $0.81 \mathrm{a}$ & $0.13 \mathrm{a}$ & $1.52 \mathrm{~b}$ & $0.10 \mathrm{a}$ \\
\hline $\mathrm{CD}$ as IPNS & $1.24 \mathrm{a}$ & $0.27 \mathrm{a}$ & $0.22 a b$ & $0.08 \mathrm{~b}$ & $0.76 \mathrm{~b}$ & $0.14 \mathrm{a}$ & $1.42 \mathrm{c}$ & $0.08 \mathrm{~b}$ \\
\hline PM as IPNS & $1.26 \mathrm{a}$ & $0.25 \mathrm{a}$ & $0.24 \mathrm{~b}$ & $0.09 \mathrm{a}$ & $0.76 \mathrm{~b}$ & $0.13 \mathrm{a}$ & $1.59 \mathrm{a}$ & $0.08 \mathrm{~b}$ \\
\hline MOC as IPNS & $1.14 \mathrm{~b}$ & $0.23 \mathrm{~b}$ & $0.22 \mathrm{~b}$ & $0.09 \mathrm{a}$ & $0.62 \mathrm{~b}$ & $0.12 \mathrm{~b}$ & $1.50 \mathrm{~b}$ & $0.08 \mathrm{~b}$ \\
\hline Control & $0.89 \mathrm{c}$ & $0.14 \mathrm{c}$ & $0.17 \mathrm{c}$ & 0.05 & $0.58 \mathrm{~d}$ & $0.10 \mathrm{c}$ & 1.28 & $0.08 \mathrm{~b}$ \\
\hline CV\% & 4.2 & 6.1 & 11.2 & 4.0 & 4.0 & 4.3 & 4.7 & 7.2 \\
\hline S.E. $( \pm)$ & 0.01 & 0.002 & 0.01 & 0.001 & 0.01 & 0.003 & 0.02 & 0.003 \\
\hline
\end{tabular}

*Means in a column followed by same letter (s) are not significantly different at $5 \%$ level of significance by DMRT 
Table 5. Effect of soil test based inorganic fertilizer and integrated plant nutrient system on N, P, K and S uptake by grain and straw of BRRI dhan29

\begin{tabular}{|c|c|c|c|c|c|c|c|c|c|c|c|c|}
\hline \multirow[t]{3}{*}{ Treatments } & \multicolumn{5}{|c|}{ Grain } & \multicolumn{4}{|c|}{ Straw } & \multicolumn{3}{|c|}{ Total } \\
\hline & \multicolumn{12}{|c|}{ Uptake $\left(\mathrm{kg} \mathrm{ha}^{-1}\right)$} \\
\hline & $\mathrm{N}$ & $\mathrm{P}$ & $\mathrm{K}$ & $\mathrm{S}$ & $\mathrm{N}$ & $\mathrm{P}$ & $\mathrm{K}$ & S & $\mathrm{N}$ & $\mathrm{P}$ & $\mathrm{K}$ & $\mathrm{S}$ \\
\hline STB & $68.89 \mathrm{c}$ & $14.30 \mathrm{bc}$ & $15.75 \mathrm{a}$ & $4.95 \mathrm{~b}$ & $38.14 \mathrm{~b}$ & $6.24 b$ & $71.70 \mathrm{~b}$ & $4.46 \mathrm{ab}$ & $107.03 \mathrm{~b}$ & $20.54 \mathrm{~b}$ & $87.45 \mathrm{~b}$ & $9.41 \mathrm{~b}$ \\
\hline $\mathrm{CD}$ as IPNS & $72.77 \mathrm{~b}$ & $15.87 \mathrm{a}$ & $12.65 \mathrm{~b}$ & $4.60 \mathrm{a}$ & $35.31 \mathrm{~b}$ & $6.42 \mathrm{~b}$ & $66.33 \mathrm{c}$ & $3.97 \mathrm{~b}$ & $108.08 \mathrm{~b}$ & $22.29 \mathrm{a}$ & $78.98 \mathrm{c}$ & $8.57 \mathrm{c}$ \\
\hline PM as IPNS & $77.25 \mathrm{a}$ & $15.39 \mathrm{ab}$ & $14.45 \mathrm{ab}$ & $5.60 \mathrm{c}$ & $43.13 \mathrm{a}$ & $7.46 \mathrm{a}$ & $90.49 \mathrm{a}$ & $4.72 \mathrm{a}$ & $120.38 \mathrm{a}$ & $22.84 \mathrm{a}$ & $104.94 \mathrm{a}$ & $10.32 \mathrm{a}$ \\
\hline MOC as IPNS & $67.44 \mathrm{c}$ & $13.49 \mathrm{c}$ & $12.73 b$ & $5.43 \mathrm{a}$ & $37.92 \mathrm{~b}$ & $7.26 \mathrm{a}$ & $91.70 \mathrm{a}$ & $4.84 \mathrm{a}$ & $105.36 \mathrm{~b}$ & $20.75 \mathrm{~b}$ & $104.44 \mathrm{a}$ & $10.27 \mathrm{a}$ \\
\hline Control & $17.08 \mathrm{~d}$ & $2.61 \mathrm{~d}$ & $3.31 \mathrm{c}$ & $1.05 \mathrm{~d}$ & $9.09 \mathrm{~d}$ & $1.60 \mathrm{c}$ & $20.08 \mathrm{~d}$ & $1.19 \mathrm{c}$ & $26.17 \mathrm{c}$ & $4.20 \mathrm{c}$ & $23.40 \mathrm{~d}$ & $2.24 \mathrm{~d}$ \\
\hline $\mathrm{CV} \%$ & 7.3 & 6.7 & 13.1 & 5.7 & 6.5 & 5.8 & 6.1 & 9.7 & 4.6 & 5.3 & 5.9 & 7.5 \\
\hline S.E. $( \pm)$ & 1.06 & 0.15 & 0.80 & 0.08 & 0.60 & 0.16 & 1.15 & 0.16 & 1.23 & 0.27 & 1.15 & 0.18 \\
\hline
\end{tabular}

*Means in a column followed by same letter (s) are not significantly different at $5 \%$ level of significance by DMRT 
Table 6. Economic analysis (cost and return) of BRRI dhan 29 production as influenced by organic and inorganic fertilizer combinations

\begin{tabular}{lllll}
\hline Treatments & $\begin{array}{c}\text { Gross return } \\
\text { BDT }\left(\text { Taka) } \mathrm{ha}^{*}\right.\end{array}$ & $\begin{array}{c}\text { Total }^{*} \text { Variable } \\
\text { cost (BDT) }\end{array}$ & $\begin{array}{c}\text { Net return } \\
(\text { BDT })\end{array}$ & BCR \\
\hline STB & 136585 & 41025 & 95560. & 3.33 \\
CD as IPNS & 131760 & 51390 & 80370 & 2.56 \\
PM as IPNS & 141585 & 48915 & 92670 & 2.89 \\
MOC as IPNS & 139600 & 113147 & 26453 & 1.23 \\
Control as IPNS & 43185 & 28975 & 14210 & 1.49 \\
\hline
\end{tabular}

* Total variable cost included land preparation, seed cost, labor cost, fertilizer cost (inorganic \& organic fertilizer), irrigation cost, pesticide cost.

Price BDT $\left(\right.$ Taka kg ${ }^{-1}$ ): Seed=35.00; Urea=20.00; TSP=22.00; $\mathrm{MP}=16.00 ;$ Gypsum=12.00; $\mathrm{ZnSo}_{4}=180.00$; $\mathrm{CD}=4.00 ; \mathrm{PM}=5.50 ; \mathrm{MOC}=39.00$

Labor wage rate $=$ Tk. 180 day $^{-1}$

**Price $($ Taka $/ \mathrm{kg}):$ Paddy $=18.50 ;$ Straw $=5.00$

\subsection{Effect of inorganic and organic nutrient management on profitability}

Net return and benefit cost ratio (BCR) of BRRI dhan29 cultivation using inorganic fertilizers alone and in combination with different organic nutrients have been shown in Table 6. The highest net return was obtained in the STB treatment followed by PM treatment. The benefit cost ratio was similar as exhibited by total net return. The BCR value ranged from 1.23 to 3.33 , where different treatments followed the order of $\mathrm{STB}>\mathrm{PM}>\mathrm{CD}>$ Control $>\mathrm{MOC}$. Mustard oil cake is costly and, therefore, BCR was found the lowest in MOC applied treatment and hence application of MOC to crop fields will not be economic. Therefore, MOC can not be recommended for farmers' practice for field crops like rice. On the other hand, even though STB fertilizers provided the maximum BCR we still recommend application of PM and CD from environmental point of view and sustainable management of soil health and crop productivity.

\section{Conclusions}

Solitary application of soil test based inorganic fertilizer and poultry manure contributed to the maximum numbers of filled grains and grain yields of rice $\left(6.11 \mathrm{t} \mathrm{ha}^{-1}\right)$. The application of different organic sources as IPNS significantly influenced the $\mathrm{N}, \mathrm{P}, \mathrm{K}$ and $\mathrm{S}$ uptake in rice, while the highest nutrient uptakes were found in the PM treatment. The highest benefit cost ratio (BCR) was found in STB inorganic fertilizer (3.33) followed by PM (2.89), CD (2.56), control (1.49) and MOC (1.23). Even though STB fertilizers provided the maximum BCR, application of $\mathrm{PM}$ and $\mathrm{CD}$ is still recommend from the environmental point of view and sustainable management of soil health and crop productivity.

\section{References}

Ali, M. E., Islam, M. R., and Jahiruddin, M. 2009. Effect of integrated use of organic manures with inorganic fertilizers in the rice-rice cropping system and its impact on soil health. Bangladesh Journal of Agricultural Research, 34(1): 81-90.

Ali, M. M., Saheed, S. M., Kubota, D., Masunaga, T. and Wakatsuki, T. 1997. Soil degradation during the period 19671995 in Bangladesh. Soil Science \& Plant Nutrition, 43: 863-890. 
BARC. 2012. Ferilizer Recommendation Guide. Bangladesh Agricultural Research Council (BARC), Farmgate, Dhaka 1215, $274 \mathrm{p}$.

BBS. 2011 (Yearbook of Agricultural Statistics of Bangladesh), Bangladesh Bureau of Statistics, Statistics Division, Ministry of Planning, Government of Bangladesh, Bangladesh, $534 \mathrm{p}$.

Bremner, J. M. 1965.Total Nitrogen. In: Methods of Soil Analysis, (ed.). C. A. Black, Agronomy 9. Madison (WI): American Society of Agronomy, 1149-1176 pp.

Gomez, K. A. and Gomez, A. A. 1984. Statistical Procedure for Agricultural Research. $2^{\text {nd }}$ Edition, International Rice Research Institute, John Wiley and Sons, New York, 680 p.

Hoque, M. S. and Jahiruddin, M. 1994. Effect of single and multiple application of sulfur, and Zinc in a continuous rice cropping pattern. Indian Journal of Agricultural Research, 28(1): 9-14.

Hossain, M. B. 1996. Integrated nutrient management for BR11 rice. MS Thesis, Department of Soil Science, Bangladesh Agricultural University, Mymensingh.

Kabir, M. S., Salam, M. U., Chowdhury, A., Iftekharuddaula, K. M., Rahman, M. S., Rashid, H., Dipti, S. S., Islam, A., Latif, M. A., Hossain, M. M. and Biswas, J. K. 2016. Rice Vision for Bangladesh: 2050 and Beyond. Keynote paper presented in the $24^{\text {th }}$ Rice Research and Extension Workshop at the Bangladesh Rice Research Institute(BRRI), Gazipur-1701 on $6^{\text {th }}$ February 2016.

Karim, Z., Miah, M. M. U. and Razia, S. 1994. Fertilizer in the national economy and sustainable environmental development. Asia Pacific Journal on Environment \& Development, 2:48-67.

Magor, N. P., Salahuddin, A., Haque, M., Biswas, T. K. and Bannerman, M., 2007.
PETRA- an experiment in pro-poor agricultural research. Dhaka (Bangladesh): Poverty Elimination Through Rice Research Assistance Project, International Rice Research Institute, $688 \mathrm{p}$.

Ofori, J., Bam, R., Sato, K., Masunaga, T., Kamidouzono, A. and Wakatsuki, T. 2005. Rice growth and yield in wasteamended West African lowland soils. Journal of Plant Nutrition, 28: 12011214.

Palaniappan, S. P. and Annadurai, K. 2007. Organic Farming: Theory and Practices, Scientific Publishers, Jodhpur, 169 p.

Rahman, M. M. 2013. Nutrient use and carbon sequestration efficiencies in soils from different organic wastes in rice and tomato cultivation. Communications in Soil Science \& Plant Analysis, 44(09): 1457-1471.

Rahman, M. M., Sultana, M., Rahman, G. K. M. M., Solaiman, A. R. M. and Alam, M. S. 2015. Effect of different organic composts on soil fertility and tomato yield. Bangladesh Journal of Soil Science, 37(1): 25-34.

Rahman, M. N., Islam, M. B., Sayem, S.M., Rahman, M. A. and Masud, M. M. 2007. Effect of different rates of sulphur on the yield and yield attributes of rice in old Brahmaputra floodplain soil. Journal of Soil \& Nature, 1(1): 22-26.

Ritamoni, B., Haridev, T., Talukdar, N. C., Baruah, R. and Talukdar, H. 1999. Soil inorganic properties as influenced by the application of fertilizers and farm yard manure (FYM). International Journal of Tropical Agriculture, 17(1-4): 153-158.

Roul, P. K. and Sarawagi, S. K. 2005. Effect of integrated nitrogen nutrition techniques on yield, N content, uptake and use efficiency of rice (Oryza sativa L.). Indian Journal of Agronomy, 50(2): 129-131. 
Shah, A. L., Islam, M. R., Haque, M. M., Ishaque, M. and Miah, M. A. M. 2008. Efficacy of major nutrients in rice production. Bangladesh Journal of Agricultural Research, 33(3): 639-645.

Sharma, A. R. and Mitra, B. N. 1991. Direct and residual effect of organic material and phosphorus fertilizer in rice (Oryza sativa L.) based cropping system. Indian Journal of Agronomy, 36(3): 299-303.

Singh, H., Verma, A., Ansari, M. W. and Shukla, A. 2014. Physiological response of rice
(Oryza sativa L.) genotypes to elevated nitrogen applied under field conditions. Plant Signaling \& Behavior, 9 (7): 29015.

Vanaja, M. and Raju, A. S. 2002. Integrated nutrient management performance in rice crop. Abbakas Agriculture Research, 23(91): 177-182.

Yamakawa, T. 1992. Laboratory methods for soil science and plant nutrients. IPSA-JICA publication No.2, IPSA, Gazipur, Bangladesh. 